\title{
Problematic of Local Head Regulation As a Local Law Products in The Framework of National Legal Development
}

\author{
Abdul Aziz Nasihuddin ${ }^{1}$, Tedi Sudrajat ${ }^{2}$ and Sri Wahyu Handayani ${ }^{3}$ \\ Faculty of Law, Jenderal Soedirman University \\ 1'ziz_lingk@yahoo.com (08122724640); ${ }^{2}$ tedi.unsoed@gmail.com; \\ 3ayu27fh@gmail.com
}

\begin{abstract}
In Indonesia, the main discusssion in the dynamics of local autonomy is the establishment of local law product after the discussion of general elections. How come? Article 18 paragraph (6) of the 1945 Constitution regulates that in the framework of implementing autonomy and co-administration duties, the local Government has the right to stipulate local regulations and other regulations. Practically, other regulations can be form as local head regulation and many kind of legal policy which made by head of local government. It can be imagined, how many local law products were established in one year in 34 provinces and 265 cities/regency. In this perspective, it is important to raises the object of Local Head Regulations as a miniature of government duties as a derivative of the Local Regulation. The problems which arrise is what is the position of local head regulation in the national legal development. This paper was conduct by doctrinal approach. The specifications which used is descriptive analysis by inventorying and identifying problems that related to harmonization and synchronization of local law products based on Law Number 12 Year 2011 concerning the Establishment of Regulations and Law Number 23 Year 2014 concerning Local Government. Analysing method is normative qualitative by using gramatical and systematic interpretation.In this study, it was found that local head regulation is a part of local law products in the form of legal policy which called as beleidregels. Based on that form, if there any substantive problems from the legal policy so it could not be tested in the legal procedure because the legal policy was made based by the freedom of government. Thats why the government should create an alternative solution to solve the substantive problems from the local head regulation as a legal policy.
\end{abstract}

Keywords: Local Head Regulations, Local Legal Products, National Legal Development

\section{Background}

On $11^{\text {th }}$ October 2016, Joko Widodo, the president of Indonesia held a limited meeting of working cabinet which results in law revitalization and reformation program. It became government's strategic agenda to bring back public trust and creates justice as well as law certainty.[1] There were three things which were instructed within the reformation policy, First, regulations arrangement to produce a good quality regulation; Second, internal reformation in the prosecutorial institution, police, also Ministry of Law and Human Rights environment in order to generate a professional service and law enforcement as the result of legal revitalization; and third, development of legal culture.[2] Consequently, Farida and Arinanto said that it needs a thorough evaluation of various legislations, including Local Head Regulation.[3] 
Sulityo, et.all stated that the implementation of local autonomy in Indonesia is aimed to encourage two points. The first one is to achieve equal people prosperity and the other one is to accelerate democracy in local level.[4] Besides, through wide autonomy area, in globalization strategic environment, region is expected to be able to increase competitiveness by paying attention to the principle of democracy, equity, justice, privilege, specialty, and potency of local diversity in Republic of Indonesia. Unfortunately, the big authority shift in region is not followed by region's readiness in form of human resources to manage the big authority. [5]

In this case, local regulation takes role as an instrument which is used to realize both of the vision. By the great amount of local law product due to the wide area of Indonesia, the study about local head regulation as local law product in developing effective national law is often ignored. The studies which have been examined so far are almost all about Local Regulation. Obviously local regulation receives more attention because it is a form of real product of democracy in local level. Local regulation is formed by two institutions which are directly chosen by community through Local Head Election.

Therefore, it is important to conduct a study on Local Head Regulation since in the local government structure, Local Head Regulation is the government regulation in Regency/City level below the Local Regulation. Thus, in fact, Local Head Regulation is the pillar in local regulation structure.

\section{Research Problem}

The problem is how to to implement local regulation or by the power of legislation, local leader stipulates Local Head Regulation. It means, local Head regulation only exists based on two matters, firstly, to carry out local regulation and secondly based on the legislation

Hence, it means that the problem is the position of Local Head Regulation as legislation as well as policy regulation.[6] Both of these positions certainly have implication on the different legal consequences as well.

\section{Methodology}

This paper used normative legal approach. It emphasizes the object on the legislation as positive law. The point of normative legal based on special legal science characteristic, which is placed on legal review or legal study about positive law, involving three layers of legal science. It consists of legal dogmatics study, legal theory, and law philosophy. In the level of legal dogmatics, the review is conducted on positive law identification especially on Local Head Regulation. Meanwhile, in the legal theory level, the theories which can be used to analyze the problem are reviewed. Furthermore, in the philosophy level, this paper is conducted to comprehend the perception of forming Local Head Regulation towards beneficial value, law certainty, and legal justice which develop among the society.

\section{Result and Discussion}

\section{a. Theory about Legislation Hierarchy}

According to legislation theory, legislation formation involves 2 (two) main points, they are: Firstly, material/substantial aspect, this aspect is related to the arrangement of legislation content that consists of legal principles and rules as well as guidance for concrete behavior in form of legal rules. As well as within the legal rules which will be defined in legislation; Secondly, formal/procedural aspect, this aspect is related to the activity of legislation formation (the efforts to comprehend method, process and technique of legislation) which takes place in particular country.[7]

Legislation holds an important role in democratic state of law in order to achieve people's prosperity. It can be seen that finally state's role is needed again after all this time people do not want their business to be interfered by the state. In the XIX century, state is requested to get involved in people's lives again which is more complex to create discipline and prosperity. [8]

In this case, law functions as the limitation of state's authority as well as people's freedom. Therefore, government and community's behavior which based on freedom rights will not disturb other people 
freedom and violates people's basic rights. In this condition, a good law is needed in which it does not just contain state's will but it also represents people's desire. The existence of norms differences and conflict between one legislation and other related legislations sometimes render difficulties for staffs in conducting their authority within government implementation. Consequently, to overcome the problem, a legal theory called "Stufenbau Theorie" is needed.

Stufenbau Theorie which is proposed by Hans Kelsen considers law process as it is depicted by norms hierarchy. Validity (mistake) from each norm (separated from the basic norm) depends on the higher norm. Hans Kelsen reveals that law arranges the formation of the law itself since a law norm determines how to form another law norm. One law norm is valid because it is made by another law norm determination and this another law norm becomes the validity of the first law norm. The relation between norms which arrange another norms formation is "super-ordination and subordination". A norm which determines the formation of another norm is the higher norm while a norm which is made by another norm is the lower norm. Legislation stage is the order of level and degree of related regulations by remembering the authorized institution and the problem which is regulated within the regulation. Kelsen discusses the validity of legal norms by depicts it as validity chain which ends up to the state constitution. The first validity constitution is the last presupposition, the final postulate, in which the validity of all norms within law structure depends. A document which is the first constitutional form is the real constitution since a norm is binding only when it is presupposed as valid. This presupposition is called transcendental-logical pressupotion.[9]

Hans Kelsen theory is related to legal norm hierarchy which forms legal pyramid (stufenbau theory). One of the figures who develop this theory is Hans Nawiasky, a student of Hans Kelsen, who develops Nawiasky theory which is called as Theory Von Stufenbau Der Rechtsordnung. The structures of norm based on the theory are:

1) State fundamental norm (Staat Fundamental Norm);

2) State Basic Law (Staat Grund Gesetz);

3) Formal Regulation (Formell Gezetz);

4) Implementation rule and autonomous rule (Verordnung En Autonome Satzung).[10]

In line with matters above, in facing norm conflict the settlement using law principles may be applied. Purnadi Purbacaraka and Soerjono Soekanto try to introduce several principles in a regulation, they are:

1) Law should not be implemented retroactively;

2) Law which is made by the higher authority has the higher position;

3) Specific laws move aside general laws (lex spesialis derogate lex generali);

4) The latest law call of the previous law (lex posterior derogate lex priori);

5) Law cannot be contested;

6) Law is an instrument to maximally achieve spiritual and material well-being for community or individual through innovation and preservation (welvaarstaats).[11]

\section{b. The Position of Local Head Regulation}

One of the consequeunces of the state of law is the development of positive law through legislation formation. In the hierarchy of legislation, Local Head Regulation may be interpreted through Article 8 Paragraph (1) and (2) Law Number 12 Year 2011 about the formation of legislation. It states that the legislations other than those mentioned in the hierarchy are still possible to exist as long as it is instructed by the higher regulation. This product of this legislation is included as delegated legislation/ secondary legislation. [12]

The first function of local head regulation is to specify the provision that still too general to be given the procedural guidance. By the role above, local head regulation is a subordinate regulation of Local Regulation. Hence, the content of local head Regulation should not against the regulation above it. In other words, Local head Regulation is one of delegated legislation products. As delegated legislation, the first area of this regulation is as legislation. 
Furthermore, in the context of government implementation, Local Leaders run the function of public service in which to implement their authority, Governor / Mayor / Regent needs compelling legal instrument. The authority to form law product inherently attached to Government corresponding to the obligation to arrange and manage public interest. [13] According to Indroharto, three reasons which underlie this authority are; the broadness of administrative law environment so that it is impossible to spill all of it in the formal law; the very fast dynamics of public service and it is impossible to be followed by change of law, even public frequently demands for quick and responsive administrative action (emergency legislation); lastly, further regulation always related to the detailed and measurable technical evaluation. Giving this legislation authority for this administration often called as "regulation", since it has the element of "policy" and "to regulate". The term "legislation" is different since it tends to refer to "legislator/law maker" the representative institution/create the law.

As the law product which is published by Local Leader in order to run public service, Local Head Regulation is obviously placed as the Legislation as well as Policy Regulation. These two different positions of Local Head Regulation obviously have an implication on different law consequences.

Local Head Regulation is published over the higher regulation and as exit clause, in which the present study reveals that the differences of legislation ratio on this Local Head Regulation formation bring consequences on the different test. The position of Local Head Regulation as legislation is a bit nondebatable. The explanation of this matter has been detailed so that without further repetition, it can be directed to another variable in which the position of Local Head Regulation as Policy Regulation.

In general, policy regulation can be defined as general regulation which is published by government (in the Executive sense) related to the duty and responsibility which attached to the authority of the government. Thus, the legal basis of policy regulation is not legislation but the authority of the government.

By seeing the position of policy regulation which is "without a hook" on the higher regulation, there is a question appears on how policy regulation can be published. Oftenly, in government implementation practice, a gap between legality and reality happens. Meanwhile, public service dynamics demand for quick action and people need the solution immediately without waiting for the existence of regulation. In order to overcome this problem, inherent freies Ermessen is given with government authority as emergency exit. Freies Ermessen is used when; Firstly, emergency situation in which it is impossible to apply written provision; Secondly, the absence of regulation which arranges the matter; Thirdly, there is the regulation which arranges the matter but the norm causes bias.

Bagir Manan mentions the characteristics of policy are: policy regulation is not a legislation; principle of limitation and examination on legislation cannot be applied on policy regulation; Policy regulation cannot be tested through wetmatigheid, since there is no basis of legislation to make a decision on the policy regulation; Policy regulation is made based on freies Ermessen and the absence of related administrative authority to make legislation; Test of law on policy regulation is given to doelmatigheid so that the test is appropriate government general principles; In practice, it is given the format in various form and type of regulations, such as decision, instruction, circular letter, announcement etc. Even in form of regulation.

General rule of legislation formation is the function of the state. For a regulation which is applied "outside", its policy regulation formation is on the government hand in a narrow sense (Executive). The general/public authority of legislation material content is different from policy regulation material content.

Sanction within policy regulation can only list administrative sanction. Meanwhile, the legislation which its formation is through people representative approval may list a sanction which limits citizen's rights.

The scope of policy regulation material content is related to the authority to form decisions in the sense of beschikkingen. It is where the authority takes action in the field of private law and the authority to arrange plans which adhered on government institution. 
The Function of Local Head Regulation as Local Regulation Implementation.

In order to run Local Government, Local Leader is given the authority to make local law product in form of regulation or even stipulation. Regulation law product is made in form of Local Regulation and Local Head Regulation which are used as the basic law of government implementation. [14]

As it is mentioned in Law Number 23 Year 2014, government gives authority for making local regulation in order to implement local autonomy and as co-administration duty or to further describe the provision of higher legislation.

According to Maria Farida Indrati, in legal norm group, there is implementation regulation (verordung) and autonomous regulation (Autonome Satzung). These regulations are placed below the Law. Implementation regulation comes from delegation authority and autonomous regulation comes from attribution authority. [15]

Therefore, it can be said that within legislation there are implementation regulation and autonomous regulation. The existence of the regulations is due to higher legislation and come from delegation and attribution authorities. Attribution authority in forming legislation (attributie van wetgevingbevoegdheid) is the authority to make legislation which is given by Grondwet (Constitution) or wet (Law) for a state institution/government. The authority attached continuously dan can be implemented on self-initiative everytime when it is needed, according to the limitation given. For example, the existence of attribution authority may be seen in Article 236 Law Number 23 Year 2014 about Local Governance. This Article gives attribution authority to Local Government to form Local Regulation in order to implement autonomy and co-administration duty. Besides, Article 238 also gives attribution authority to Local Government to form Local Regulation that contains imprisonment sanction at most 6 (six) months or fine at most Rp. 50.000.000,- (Fifty million rupiah).

What is meant by delegation authority in legislation formation (delegatie van wetge-vingsbevoegdheid) is delegation of authority to form legislation which is done by the higher legislation towards the lower legislation, whether the delegation is stated boldly or not. Meanwhile, attribution authority is different. The authority in delegation authority is not given but it is represented. Besides, this delegation authority is temporary as long as the delegation still exists.

\section{Local Head Regulation Implementation in Banyumas Regency.}

The authority of forming Local Regulation is a sign of region's independence in managing their own interest. Local Regulation is a strategic instrument to achieve decentralization purpose. In the context of local autonomy, the existence of Local Regulation is encouraging decentralization optimally. [16]

From the political empowerment point of view, decentralization may be seen from two sides, they are local government and central government. The purpose of decentralization from local government point of view is to realize political equality, local accountability and local responsiveness. Meanwhile, in central government point of view, the purpose of decentralization is to realize political education, provide training in political leadership and create political stability. [17]

To implement Local Regulation over legislation, local leader stipulates Local Head Regulation. The provision about formation principle and material content as well as local regulation formation as it is mentioned in Article 237, is applied mutatis mutandis over the formation principle and material content of Local Head Regulation.

Local Regulation and Local Head Regulation are prohibited to against the higher legislation, public interest and/or morality. What is meant to against public interest, are:

1) Disturbing harmony between citizens;

2) Disturbing access for public service;

3) Disturbing public safety and discipline;

4) Disturbing economical activity to increase people's prosperity; and/or

5) Discrimination over ethnic group, religion, belief, race, groups and gender. [18] 
Based on the information from Head of Subdivision regulation and Head of Subdivision DH, Legal Division of Banyumas Regency, since 2010-2015 there are 406 Local Head Regulation, 80\% (325 regulations) of them are made based on the delegation of the higher regulation and the rest ( 81 regulations) of them are not based on the higher regulation or it is published as exit clause. The delegation regulations do not cause any problem, but what about the exit clause? Theoretically, it can be understood because the dynamics of public service is very fast and it is impossible to be followed by the change of Local Regulation or any legislation above it. Even, public often demands for a quick and responsive administration action (emergency legislation); the other reason is that further regulation always related to detailed and measurable technical evaluation.

\section{Conclusion}

In this research, the result shows that Local Head Regulation is a part of local law product in form of policy regulation, so that it cannot be tested with wetmatigheid. Policy regulation is made based on freies Ermessen and the absence of related administrative authority to make legislation as long as it has a strong reason or emergency condition to make written provision; secondly, the absence of the regulation that arrange the matter; thirdly, there is a regulation which arranges the matter but its norm causes bias.

\section{Acknowledgement}

This article is intended to be obtained argumentation academically through the ideal concept local head regulation. Support from Ministry of Research and Higher Education is gratefully acknowledged.

\section{References}

[1] Thirzano, Yudie, (2017).Reformasi Hukum Bergulir Sesuai Nawacita, Tribun News 13 Oktober 2016, http://www.tribunnews.com/nasional/2016/10/13/reformasi-hukum-bergulir-sesuainawacita, accessed on 5th of October 2017.

[2] Kartika, Shanti Dwi, (2016). Pembentukan Kebijakan Reformasi Hukum, Majalah info singkat hukum, vol. VIII, No. 19/I/P3DI/October/2016

[3] Farida, Ike and Arinanto, Satya, (2017). Penataan Peraturan Pelaksana Putusan Mahkamah Konstitusi (Studi Kasus Putusan Nomor 27/PUU-XIII/2011) di dalam Penataan Ulang Jenis dan Hierarki Peraturan Perundang-Undangan Indonesia, Jakarta: Research Body of Indonesian People's Consultative Assembly

[4] Sulistyo, Yuri, et, all, (2014). Pengawasan Pemerintah Terhadap Produk Hukum Daerah (Perda) Melalui Mekanisme Pembatalan Perda Berdasarkan Undang-Undang Nomor 32 Tahun 2004 Tentang Pemerintahan Daerah, e-Journal Lentera Hukum, I (1): 1-12.

[5] Kurniawan, (2013) Pembentukan Produk Hukum dalam rangka Penyelenggaraan Kanun, Jurnal Ilmu Hukum XV (61) : 519-546.

[6] Syihabudin, (2003). Kajian terhadap Jenis dan Tata Urutan Peraturan Perundang-undangan Indonesia, Law Journal. 23 (10):46 - 71

[7] Faculty of Law Unpar, (1977). Keterampilan Perancangan Hukum. Bandung: PT Citra Aditya Bakti

[8] Hadjon, Philipus M., (1987). Perlindungan Hukum Bagi Rakyat, Surabaya: PT Bina Ilmu.

[9] Kelsen, Hans, (1945). General Theory of Law and State, New York:Russell \& Russell.

[10] Attamimi, A.Hamid, (1990).Peranan Keputusan Presiden Republik Indonesia Dalam Penyelenggaraan Pemerintahan Negara; Suatu Studi Analisis Mengenai Keputusan Presiden yang Berfungsi Pengaturan Dalam Kurun Waktu Pelita I-Pelita IV. Jakarta: Legal Science Dissertation of Postgraduate Faculty of UI.

[11] Yuliandri (2011) Asas-Asas Pembentukan Peraturan Perundang-Undangan Yang Baik Gagasan Pembentukan Undang-Undang Yang Berkelanjutan, Cetakan ketiga, Jakarta: PT Raja Grafindo Persada. 
[12] Jimly Asshiddiqie, (2005). Perihal Undang-Undang, Secretariat General of the Constitutional Court.

[13] Ridwan, (2009). Tiga Dimensi Hukum Administrasi dan Peradilan Administrasi, FH-UII, Press, Yogyakarta

[14] Aryani, Sylvia (2017). Eksistensi Peraturan Kepala Daerah Sebagai Peraturan Pelaksana Peraturan Daerah, Badamai Law Journal, 2 (1).

[15] Indrati, Maria Farida, (2007). Ilmu Perundang-Undangan I; Jenis, Fungsi dan Materi Muatan, Yogyakarta, Publisher Kanisius

[16] Rawasita, Reny, et.all (2009). Menilai Tanggung Jawab SosialPeraturan Daerah, Indonesian Center of Law and Policies Studies (PSHK), Jakarta

[17] Hidayat, Syarif, (2006). Desentralisasi untuk PembangunanDaerah, Jentera: Regional Regulation.

[18] Zein, Yahya Ahmad, (2017). Hierarki Peraturan Perundang-Undangan Indonesia (Studi Pasal 8 ayat (1) UU No. 12 Tahun 2011 tentang Pembentukan Peraturan Perundang-Undangan), Jakarta: Research Body of Indonesian People's Consultative Assembly. 